\title{
Study on the Cultivation of American Civic Cultures in Contemporary China*
}

\author{
Wang Yongquan \\ Department of Foreign Languages, Henan Institute of Engineering, Zhengzhou 451191, P.R. China \\ Wangyongquan268@sina.com
}

\begin{abstract}
The introduction of English and American civic cultures to China is beneficial to the development of its traditional cultures, and it is necessary for contemporary China to enhance the cultivation of civic cultures to realize its modernizations. Western civic cultures include citizen awareness, values, attitudes, moralities, legal senses, confidence and so on, which is a unity of ideas, mentality, behavioral norms and common practices. The cultivation of civic cultures in China entails forms and contents of public participation in politics to be enriched. The aim is to combine American civic cultures with Chinese political cultures and enrich Chinese cultures. Some methods as deduction, illustration are used. The result is civic cultures are further realized and enhanced in China.

Index Terms - American civic cultures; Chinese society; cultivation; modernizations
\end{abstract}

\section{Introduction}

Civic cultures originated from America in the 60s of the $20^{\text {th }}$ century. Since World War II, many scholars like Almond, an American professor, have explored the necessities of building up democracy, from such different angles as democratic systems, politics, political psychology, political order, political development, social capital and so on. The cultures are introduced into China and studied in the 80s of the $20^{\text {th }}$ century. In contemporary China, civic cultures must be cultivated for leading political cultures to strengthen most citizens' confidence in democracy, with the excellent cultures deposited in the national spirit for political modernization. The paper first explores why and how to cultivate civic cultures in China more systematically than ever.

\section{The Definition of Civic Cultures in Contemporary China.}

Civic or political cultures are a kind of national psychology in political life, which includes the prevailing attitudes, beliefs and values among the citizens in a country. The theory of civic cultures has been studied for ages since introduced from America and Europe to China. Shi Xue Hua, a Chinese scholar, said, " Civic cultures mean a system of values based on civil freedom and equality, a unity of attitudes, beliefs, emotions, evaluation and norms, including freedom, equality, rights, obligations and so on."[2] Other scholars also think that civil cultures mean democratically civil attitudes, emotions and so forth, "belonging to the hidden structure of democracy."[3]

In contemporary China, modern citizens with civic cultures are characterized by: 1) Most of citizens are common to have human rights, civil rights and awareness of independence, and they can get out of the complex of yes-men. Human rights are of different sorts, such as freedom, equality, property, security, rights of seeking for happiness and countering against oppression. 2) Root out adoration and fascination of rights, eliminate despotism, improve right supervision and build up democratic senses. 3) Set up modern elective systems. Solve the right sources and supervision issues to get rid of the malady of attaching oneself to powerful people, really show affection to people, be in power for people and of benefit to people. 3) Safeguard human rights and democratic legislation, with law to be supreme, most impartial and independent to regulate powers and officials. 4) Senses of responsibility. All the citizens must be made clear that any right cannot be born naturally, but won over, treasured, preserved, developed and enjoyed by every citizen to take responsibility.

\section{Necessities of Cultivating Civic Cultures in Contemporary China}

Politics in every society is rooted in tradition and influenced by other civilizations. China, with a long history, obviously has its politics developing with Chinese characteristics. Since the Qin Dynasty, the despotic system had been founded on the basis of counties. Meanwhile, in the natural economy with agriculture as the core, the ethical and moral systems with such nuclear values as the Confucian doctrines: propriety, righteousness, kindness, intelligence and credit have evolved into the political philosophy and ideas of harmony, order and stability. While traditional Chinese politics have been lost, its essential philosophy is still influential in current political life.

The rooted subjection cultures in feudal China are obviously incompatible with such political conceptions of people in power, democracy and law, which still impede the development of socialist civic cultures as the bottleneck of China's all-round modernizations, and need to be superseded by civic society and civic cultures.

\footnotetext{
* The paper is the initial accomplishment of the program assigned by Henan Science and Technology Department in 2013: A Study on the Translators in Phenomenological Perspective in Henan. $\quad$ No:132400410300
} 
The civic cultures in the European industrialization were based on the dominant value systems of freedom, equality, fraternity and democracy after the French Revolution. As mentioned above, the subjection psychology has resulted from the dominant "three cardinal guides and five constant virtues" in feudal China and will be influential in China. Similarly, the deep-rooted cultural psychology of subjection results from the feudal propriety and education, and will influence China's political ecology in the long run. Nearly one-century development of Chinese society has proved, loss of civic awareness is the major part to limit China's modernization process. The feudalism has been rooted out politically in history and criticized fiercely culturally, but its political cultures have been sedimentary for long and formed moralities, ethics, mentalities and cultural psychology, which are not rooted out and still in charge of people's ideas, behaviors and values in the form of sub-consciousness. Large quantities of tragic incidents and difficulties at the turn of society are mostly connected with it. The essential part of society is formed by society, economy, politics and cultural concepts to contribute its integrity. Therefore, civic cultures were and will be impeded by the subjection cultures.

How can civic awareness be cultivated? The cultivation cannot be weakened. "When people have been modernized psychologically and behaviorally, and administrators in all fields have been suitable the modern environment, the country is really up to date. If not, the fast and stable economy and effective management cannot be realized. Even if economy has taken off, it will not be long."[4]

\section{Measures to Cultivate Civic Cultures in China}

\section{1) Fostering Civil Consciousness of Rights}

The civil consciousness of rights is the concrete form of civic awareness and the refection of the ideas. It is as follows: firstly, the legal rights and values are ensured to be understood; secondly, methods of preserving the rights are grasped by citizens; thirdly, the citizens' actions in utilizing rights must be regulated by law to be exclusive of the harm of other citizens. The awareness of right is the logical precondition of consciousness generation and existence. With the consciousness, the dominant self can be found and citizens are consciously practicing the rights.

\section{2) Development of the Awareness of Civil Participation}

Political life is the primary democracy, with citizens participating in political activities in different ways and affecting political constitution and policy. It is the most important way of realizing civil rights, and shows the connections between citizens and rights, obligations and responsibility. Citizens consciously realize rights through participating and affecting its tendency, process and results. The consciousness determines actions. Problems can be solved in frequent participations. The important issues are discussed and supervised in congress of representatives, political consultative congress, and so on. With the establishment of market economy, new social structures and classes have surfaced and become pluralistic.

\section{3 ) Fostering of Civil Awareness of Equality}

The civil consciousness of equality means citizens' requirement for values and essential condition of socialist politics and democracy. It includes equalities of citizens' social status, legal rights and opportunities to take part in politics.

\section{4 ) Development of Civil Consciousness of Law}

Civil consciousness of law reflects citizens' democratic self-defense is realized. It contains natural identification and respect of law, obeying law and combating illegal activities. With consciousness of law and its practice, a better legal environment is formed to guarantee the basic and orderly democracy and politics for socialism and civil legal actions.

\section{5) Development of Civil Awareness of Responsibility}

Awareness of responsibility shows the rise of subjectivity, guaranteed by citizens' legal rights to shoulder their responsibility. Traditionally, every citizen is responsible for the harmonious and healthy development of society. However, as the individual was not able to be prominent traditionally in a collective group and the collective responsibility was too heavy, great gap appeared between responsibility and citizens' ability to take it. As a result, the awareness of responsibility diminishes due to loss of individual responsibility and goal in political life. With the improvement of market economy, the socialist democracy and politics are taking shape and citizens gaining full freedom and rights, which is likely and necessary. When senses of responsibility are built up, citizens participate in politics more effectively and willingly to enhance their competence to take part.

\section{Conclusion}

It should be clear that the cultivation of civic cultures in China is not a simple change of conception but deeply connected with the adjustment of all social structures, improvement of social system, enhancement of citizens' quality and so on. The efforts are to be made by all levels of society to further the development of civic cultures and socialist modernization with Chinese characteristics. Cultivation of civic cultures is not only necessary for socialist modernization but also for China catering for the tendency of globalization.

\section{References}

[1] Almond Bowel: Comparative Politics-System, Process and Policy.Trans. by Cao Pei Lin. Shanghai: Shanghai Translation Press, 1989. p.15.

[2] Xue Hua Shi: Theories of Politics . Guangzhou: Zhongshan University Press, 2001. p.12.

[3] Ri Yun Cong: the Educational Function of Democracy for Citizens . Journal of Tianjin Communist Party Committee School, 2001, Vol.1. pp.39-43.

[4] Engels: Human Modernization-Psychology, Ideas, Behaviors . Trans. By Lu Jun Yin. Chengdu: Sichuan People’s Publishing House, 1985. p.8. 